\title{
Determinants of Rice Productivity: An Analysis of Jaffarabad District -Balochistan (Pakistan)
}

\author{
Sarfaraz Ahmed Shaikh \\ Ouyang Hongbing
}

School of Economics, Huazhong University of Science and Technology, Wuhan. P.R. China

\section{Khalid Khan}

Masood Ahmed

Department of Economics, Lasbela University of Agriculture, Water and Marine Sciences, (LUAWMS), Uthal, Balochistan, Pakistan

\section{doi: 10.19044/esj.2016.v12n13p41 URL:http://dx.doi.org/10.19044/esj.2016.v12n13p41}

\begin{abstract}
This study examines the determinants of rice production in the district of Jaffarabad in Balochistan using primary data. The data is collected with the help of well-developed questionnaire based on random sampling from the different tehsils of Jaffarabad district. In this study, we estimated the parameters of the Neo-classical and Cobb-Douglas production function with the help of ordinary least square (OLS) method. The results of this empirical work show that with the exception of experience of farmers and high cost of the inputs, all explanatory variables i.e. capital, labor, education of the farmers, availability of credit and farm size have a positive effect on rice output. Therefore, government is recommended to encourage farmers to use fertilizers and new methods in agricultural production and watering, and provide them with convenient loans at low interest rate.
\end{abstract}

Keywords: Neo-Classical Production Function, Cobb-Douglas Production Function, Ordinary Least Square (OLS), Rice Production, Jaffarabad

\section{Introduction}

Pakistan is an agrarian economy; and agriculture is the backbone of Pakistani economy. Agriculture is the second largest sector of the economy whose contribution to GDP stands at 21.5 percent and provides employment to 43.5 percent of the total labor force (GoP, 2015). Sixty one percent of the population of Pakistan which lives in rural areas (NIPS, 2016), is directly and indirectly dependent on agriculture sector for their livelihood. Agriculture also contributes significantly to the exports of Pakistan, as 66 
percent of export earnings come from agriculture sector (GoP, 2015). Agriculture does also have forward linkage to different types of industries. The Agriculture Industry in Pakistan consists of livestock, forestry, fishing, food and cash crops i.e. Rice, wheat, maize, cotton, sugarcane, beans, Gram, Barley and Tobacco. The total area of agricultural land is 34.89 million hectares while total arable land is 30.34 million hectares (PBS, 2016).

Balochistan, with respect to area is the largest province of Pakistan and it is about 43 percent of the total area of Pakistan but is smallest in population as compared to all others provinces. Balochistan has a long costal belt, which is 11000 kilometer long. The total agricultural land in Balochistan is 7.32 million hectares while the arable land is 5.96 million hectares. Among all the districts of Balochistan, Nasirabad and Jaffarabad are considered to be most fertile and give high yields in terms of Agricultural output. Rice is the second staple of food used in Pakistan after wheat and the second largest earner of foreign exchange after cotton. In 2009 Pakistan produced 6883 thousand tons of rice and it was cultivated on 2883 thousand hectares(GoP, 2015).

Few of the important researches which address the issues like this one are , (Mundlak, Larson, \& Butzer, 1997), (Hussain \& Ishfaq, 1998), (Iqbal, Khan, Ahmad, \& Ahmad, 2001), (Akinbile, 2007) and (Olujenyo, 2008). All these researches have tried to show the determinants of agriculture productivity for different agriculture crops. In Pakistan (Iqbal et al., 2001) found out the determinants of wheat production and similarly (Mundlak et al., 1997) conducted the research to study the effects of agriculture productivity on poverty reduction of the farmers.

The main objective of our study is to identify the determinants of the rice productivity in district Jaffarabad of Balochistan. The rest of the paper is organized in such a manner that section 2 offers the methodology of the paper; results and discussion are in section 3 , and finally section 4 concludes the paper.

\section{Methodology and Data Data \& Sampling}

This study used primary data that was collected through questionnaires; one hundred and twenty respondents were selected with the help of random sampling and based on judgment sampling two villages were selected from each Tehsil of district Jaffarabad.

This study is limited to only one district i.e. Jaffarabad. , Jaffarabad is the 2nd most populated district of Balochistan having about 0.64 million of population (Unicef \& GoB, 2011). The total area of the district is 2445 square kilometers. Jaffarabad district is situated near to the border of Sindh province. The south of the district Jaffarabad touches the district of 
Shahdadkot and Jacobabad in Sindh, to the North of it is Nasirabad, to its West is the district of Jhal-Magsi and in East lays Dera-Bugti. Jaffarabad is a plain agricultural area and it is the most productive district of Balochistan. The main source of income of the people in this district is agriculture; about 90 percent of the population of the district is directly and indirectly related to agriculture. The major crops of the district are wheat and rice. This study is focused, only to find out the determinants of rice production in district Jaffarabad. District Jaffarabad consists of four Tehsils, forty-six union councils and 235 villages.

Due to financial and time constraints, the study only investigates two villages from each Tehsil of district Jaffarabad, villages were selected on the basis of judgment sampling, among the eight villages 120 samples were selected randomly with help of the following formula;

$$
N I=\frac{n}{N} \times N i
$$

Where

$N I=$ number of the respondents in each village

$i=$ Numbers of the $N_{1}=$ villages

$n=$ total sample size i.e 120

$N=$ total number of the farmers in the targeted (population)

$\mathrm{Ni}=$ total number of the farmers in each village

No. of Respondents selected from each Village

$N_{1}=$ Number of respondents in Mewa Khan Village

$$
=\frac{n}{N} \times N i=\frac{120}{2229} \times 200=10.76=11
$$

$N_{2}=$ Number of respondents in Musa Lashari Village

$$
=\frac{n}{N} \times N i=\frac{120}{2229} \times 250=13.45=13
$$

$N_{3}=$ Number of respondents in Head Bage village

$$
=\frac{n}{N} \times N i=\frac{120}{2229} \times 421=22.66=23
$$

$N_{4}=$ Number of respondents in Gandakha City village

$$
=\frac{n}{N} \times N i=\frac{120}{2229} \times 357=19.22=19
$$

$N_{5}=$ Number of respondents in Rojhan Jamali village

$$
=\frac{n}{N} \times N i=\frac{120}{2229} \times 281=15.12=15
$$

$N_{6}=$ Number of respondents in Abdullah Pandrani village 


$$
=\frac{n}{N} \times N i=\frac{120}{2229} \times 231=12.44=12
$$

$N_{7}=$ Number of respondents in Gulam Mohammad village

$$
=\frac{n}{N} \times N i=\frac{120}{2229} \times 311=16.74=17
$$

$N_{8}=$ Number of respondents in Kashmir kot village

$$
\begin{aligned}
& =\frac{n}{N} \times N i=\frac{120}{2229} \times 178=9.58=10 \\
& \text { Total }=
\end{aligned}
$$

\section{Descriptive Statistics}

Table .1: Age of the Respondents

\begin{tabular}{ccc}
\hline Age & Frequency & Percentage \\
\hline $25-35$ & 18 & 0.15 \\
$35-45$ & 51 & 0.43 \\
$45-55$ & 25 & 0.21 \\
$55-65$ & 16 & 0.13 \\
$65-75$ & 10 & 0.08 \\
\hline Total & 120 & 100 \\
\hline
\end{tabular}

The table 1 presents the age distribution of the farmers in district Jaffarabad. It shows that age of the farmers was between 25 and 75 years, the 43 percent of the farmers were aged between 35 and 45 years while 42 percent of the farmers had experience of 31 to 45 years. Therefore on the basis of these facts, we can say that most of the farmers related to rice production in district Jaffarabad are mature and experienced.

Table. 2: Educational Level of the Respondents

\begin{tabular}{ccc}
\hline Educational Level & Frequency & Percentage \\
\hline Illiterate & 51 & 0.43 \\
Primary & 36 & 0.30 \\
Metric & 21 & 0.17 \\
Secondary & 09 & 0.08 \\
Graduate & 03 & 0.02 \\
\hline Total & 120 & 100 \\
\hline
\end{tabular}

Table 2 shows the educational status of these farmers. About 43 percent of the farmers are illiterate, only 30 percent of the farmers have primary education and just 18 percent had passed matric. Therefore due to the high illiteracy among farmers, they cannot adopt the new techniques and technologies related to modern farming and in this way they only concentrate on their old farming methods. Furthermore, due to high illiteracy, 60 percent of the farmers market their output through a middleman while just 32 percent farmers market their output directly. 
Table. 3: Income Level of the Respondents

\begin{tabular}{ccc}
\hline Income & Frequency & Percentage \\
\hline $10000 \leq$ & 70 & 0.58 \\
$20000 \leq$ & 28 & 0.23 \\
$30000 \leq$ & 15 & 0.13 \\
$40000 \leq$ & 07 & 0.06 \\
\hline Total & 120 & 100 \\
\hline
\end{tabular}

Table 3 offers the allocation of the farmers' income. Fifty eight percent of the farmers' monthly income is less than PKR 10,000, only 23 percent of the farmers have income of PKR 20,000 per month. It shows that most of the farmers are poor and they are below the poverty line. In addition, because of financial constraints they are not able to invest on their farms. Therefore, the poverty of the farmer affects the productivity of the farm negatively.

Table 4: Source of Financial Support

\begin{tabular}{ccc}
\hline Source & Frequency & Percentage \\
\hline Government bank & 10 & 0.08 \\
Private bank & 05 & 0.04 \\
ZTBL & 36 & 0.30 \\
Informal sector & 69 & 0.58 \\
\hline Total & 120 & 100 \\
\hline
\end{tabular}

Table 4 shows the availability of credit facility to the farmers, 58 percent of the farmers get loans from the informal sector i.e. land lord, middleman etc. while 30 percent of the farmers gets loans from ZTBL bank (A bank which supports agriculture financing).

Table 5: Source of Marketing

\begin{tabular}{ccc}
\hline Source & Frequency & Percentage \\
\hline Direct & 38 & 0.32 \\
Middle man & 79 & 0.66 \\
Agencies & 03 & 0.02 \\
\hline Total & 120 & 100 \\
\hline
\end{tabular}

Table 5 shows the sources of marketing and selling of products adopted by farmers. Only 32 percent of the farmers directly sell their products to the market and eliminate the share of middleman. However, the majority i.e. 68 percent sells their products to middleman or agencies and they don't enjoy full profit of their efforts.

Table 6: Farm Size of the Respondents

\begin{tabular}{ccc}
\hline Farm size (hectares) & Frequency & Percentage \\
\hline$\leq 1.5$ & 25 & 0.21 \\
$1.5-3$ & 64 & 0.53 \\
$3-4$ & 31 & 0.26 \\
\hline Total & 120 & 100
\end{tabular}


Table 6 shows that majority of the farmers in the study area are small scale farmers, 74 Percent of the farmers having only 3 or less than 3 hectares of land while only 31 percent of farmers holds more than 3 hectares of land.

Table 7: Gender Distribution of the Respondents

\begin{tabular}{ccc}
\hline Sex & Frequency & Percentage \\
\hline Male & 103 & 0.86 \\
Female & 17 & 0.14 \\
\hline Total & 120 & 100 \\
\hline
\end{tabular}

Table 7 shows that ratio of male and female among the farmers in our targeted area. Majority of the farmers in the study area are male, 86 percent of the farmers are male while females form only $14 \%$ of the work force in farming profession.

Table 8: Year of Experience of the Respondents

\begin{tabular}{ccc}
\hline Years of experience & Frequency & Percentage \\
\hline $1-15$ & 27 & 0.22 \\
$16-30$ & 37 & 0.31 \\
$31-45$ & 50 & 0.42 \\
$46-60$ & 06 & 0.05 \\
\hline Total & 120 & 100 \\
\hline
\end{tabular}

Table 8 shows the experience level of the farmers. About 22 percent of the farmers have experience of less than 15 years, while 31 percent have experience between 16 to 30 years. But the half of the farmers has very long experience of more than 30 years. We can say that this half has spent almost all of their life in farming profession.

\section{Model Specification}

The pioneers of agriculture production functions are (Tintner, 1944) and (Heady, 1946), but the study used the simple form of Neo-Classical production function. Therefore, the functional form of the agriculture production can be represented as in the following form; $Y_{t}=f\left(L_{t}, K_{t}, Z\right)$.

Where agricultural output $\left(Y_{t}\right)$ is a function of labor $\left(L_{t}\right)$,physical capital investment $\left(K_{t}\right)$, and a vector $\mathrm{Z}$ for other determinants, which captures education of the farmers, cost of inputs, experience of farmers, availability of credit, farm size, and age of the farmers. Thus, the regression model of the production function is as follow;

$\log Y_{t}=\beta+\beta_{1} \log L_{t}+\beta_{2} \log K_{t}+\beta_{3} \log X_{1}+\beta_{4} \log X_{2}+\beta_{5} \log X_{3}+\beta_{6} \log X_{4}$

$+\beta_{7} \log X_{5}+\beta_{8} \log X_{6}+\varepsilon_{t}$

Where

$Y_{t}=$ Agriculture output 
$L_{t}=$ Labor

$K_{t}=$ Capital

$X_{1}=$ Education of the farmers

$X_{2}=$ Cost of the inputs

$X_{3}=$ Experience of the farmers

$X_{4}=$ Availability of credit

$X_{5}=$ farm size

$X_{6}=$ Age of the farmers

$\varepsilon_{t}=$ Residual term.

Furthermore, we also used Cobb-Douglas production function, which is specified as $Y=A K^{\alpha} L^{\beta}$

Where $\mathrm{Y}$ is output, $\mathrm{K}$ is capital and $\mathrm{L}$ is labor inputs while $\mathrm{A}$, $\alpha, \beta$ are the parameters determining the production technology.

If $\alpha+\beta=1, \alpha+\beta<1$ and $\alpha+\beta>1$ then production will be subject to the constant return, decreasing return and increasing return to scale respectively.

For estimation of the Cobb-Douglas production function we take log of equation (3), then it becomes $\log Y=\log A+\alpha \log K+\beta \log L$

Before estimating the model, let us examine the signs of the variables based on economic theory. The sign of labor and capital is expected to be positive because both are the crucial determinants of productivity. Positive signs are also expected for education of the farmers, availability of credit, and farm size, while for high cost of inputs and experience of farmers negative signs are expected because most of the experienced farmers use their traditional methods of productivity rather than new and sophisticated methods.

\section{Results and Discussion}

At this step, we have estimated the best population parameters for equation (2) and (4) and for this purpose; we have used the method of least square, which is commonly known as ordinary least square (OLS). Results of the said functions are presented in table 9. 
Table 9: Results of Cobb-Douglas and Neo-Classical Production Function

\begin{tabular}{|c|c|c|c|c|c|}
\hline \multicolumn{3}{|c|}{ Cobb-Douglas Production Function } & \multicolumn{3}{|c|}{ Neo -Classical Production Function } \\
\hline Variables & Coefficient & $\begin{array}{c}\text { T- } \\
\text { values }\end{array}$ & Variables & Coefficients & $\begin{array}{c}\text { T- } \\
\text { values }\end{array}$ \\
\hline Constant & $1.032 * * *$ & 3.540 & Constant & $1.230^{*}$ & -2.611 \\
\hline $\log L_{t}$ & $0.410^{* * *}$ & 5.130 & $\log L_{t}$ & $0.312^{* * *}$ & 4.370 \\
\hline \multirow[t]{7}{*}{$\log K_{t}$} & $0.590 * *$ & -2.880 & $\log K_{t}$ & $0.531 * * *$ & 4.760 \\
\hline & & & $\log X_{1}$ & $0.065^{*}$ & 1.967 \\
\hline & & & $\log X_{2}$ & $-0.042 * *$ & -4.898 \\
\hline & & & $\log X_{3}$ & $-0.020^{*}$ & 1.795 \\
\hline & & & $\log X_{4}$ & $-0.142 *$ & 1.751 \\
\hline & & & $\log X_{5}$ & $0.041^{*}$ & -1.961 \\
\hline & & & $\log X_{6}$ & $0.013^{* *}$ & -2.133 \\
\hline \multicolumn{2}{|c|}{ R-square } & 0.650 & \multicolumn{2}{|c|}{ R-square } & 0.60 \\
\hline \multirow{2}{*}{\multicolumn{2}{|c|}{$\begin{array}{l}\text { DW } \\
\text { SF }\end{array}$}} & 1.942 & \multirow{2}{*}{\multicolumn{2}{|c|}{ DW }} & 2.10 \\
\hline & SE & 0.031 & & & 0.012 \\
\hline
\end{tabular}

Note: The variables on the $(*, * *, * *)$ are statistically significant at level of $(10,5,1)$ percent respectively

The coefficients of labor and capital are extremely significant and the values of the coefficients of labor and capital in Cobb-Douglas production are 0.41 and 0.59 respectively. It can be interpreted that on average a 1 percent increase in labor will leads to increase of 46 percent in output. Similarly 1 percent increase in capital will increase output of rice by 61 percent on average.

In neo-classical production function, all of the variables have correct signs and are significant in different conventional level. The increase of the labor and capital have a positive effect on rice productivity which shows that in Jaffarabad district rice farms still have the capacity to absorb more labor force. Based on this evidence, we can say that the production of rice is subject to constant return which is already shown by the Cobb-Douglas production function. The effect of capital is stronger than that of labor because capital can play an important role in increasing the agricultural productivity.

The farmers' education affect the rice productivity positively as we expected, a one percent increase in the farmers' education will increase the rice production by 0,065 on average, because educated farmer adopts modern methods of farming, watering and ensure the use of new technologies. 
The negative sign of the coefficient of cost of inputs supported by law of demand, most of the farmers in district Jaffarabad only earn the subsistence level of income from agriculture and they are not able to use high cost inputs in agriculture production as per requirement of the crop. The coefficient of input cost shows that a one percent increase in cost of inputs means that on average 0.042 decreases in rice production. Similarly the coefficient of farmers experience is also having negative sign as expected because the farmer with long years of experience is using obsolete methods of farming while availability of credit, farm size and age of the farmers have a positive effect on the rice productivity. Even though, most of the farmers take loans from informal sector.

\section{Conclusion}

The study examined the determinants of the rice production at district Jaffarabad in Balochistan. The data was collected based on a well-developed questionnaire. One hundred and twenty samples were selected based on random sampling technique. First, we selected two villages from each tehsil based on judgment sampling and then 120 samples were selected form these villages randomly. All determinants have positive effect on the rice production in district Jaffarabad except for experience of farmers and high cost of inputs; because experienced farmers always hesitate to adopt the new methods and technologies in agricultural production process and usually they use their conventional methods of production.

Therefore, it is the responsibility of government to encourage farmers to use fertilizers and new methods in agricultural production and watering, and provide them convenient loans on low interest rate (through one window operation) and educate the farmers through adults' education programs in evenings.

\section{References:}

Akinbile, L. (2007). Determinants of productivity level among rice farmers in Ogun State, Nigeria. Paper presented at the Eighth African Crop Science Conference Proceedings.

GoP. (2015). Economic Survey 2014-15. Finance Division, Economic Advisor's Wing, Government of Pakistan ,Islamabad.

Heady, E. O. (1946). Production functions from a random sample of farms. Journal of Farm Economics, 28(4), 989-1004.

Hussain, S. T., \& Ishfaq, M. (1998). Dynamics of Agricultural Productivity and Poverty in Pakistan.

Iqbal, M., Khan, M. A., Ahmad, M., \& Ahmad, B. (2001). Determinants of Higher Wheat Productivity in Irrigated Pakistan [with Comments]. The Pakistan Development Review, 753-766. 
Mundlak, Y., Larson, D. F., \& Butzer, R. (1997). The determinants of agricultural production: a cross-country analysis: World Bank Publications. NIPS. (2016). National Institution of Population Studies. Islamabad, Pakistan.

Olujenyo, F. O. (2008). The determinants of agricultural production and profitability in Akoko Land, Ondo-State, Nigeria. Journal of Social Sciences, 4(1), 37-41.

PBS. (2016). Land Utilization Statistics. Federal Bureau of Statistics, Islamabad, Pakistan.

Tintner, G. (1944). A note on the derivation of production functions from farm records. Econometrica, Journal of the Econometric Society, 26-34.

Unicef, \& GoB. (2011). District Development Profile - Jaffarabad. Planning \& Development Department, Govenment of Balochistan and Unicef Provincial Office Balochistan. 